\title{
KARAKTERISTIK SESEORANG DALAM MENCARI JALAN DI JABODETABEK
}

\author{
Pratama Kurnia Jaya Kusuma $^{1}$ dan Leksmono Suryo Putranto ${ }^{2}$ \\ ${ }^{1}$ Program Studi Sarjana Teknik Sipil, Universitas Tarumanagara, Jl. Letjen S. Parman No.1 Jakarta \\ pratama.kurnia.325150135@stu.untar.ac.id \\ ${ }^{2}$ Program Studi Sarjana Teknik Sipil, Universitas Tarumanagara, Jl. Letjen S. Parman No.1 Jakarta \\ lexy_putranto@gmail.com
}

Masuk: 17-01-2020, revisi: 15-05-2020, diterima untuk diterbitkan: 15-05-2020

\begin{abstract}
Transportation arise as result of human activity to fulfil their daily needs that cannot be achieved in their current location. This activity is influnced by the characteristics of everyone in finding a way. A person's characteristics are certainly influnced by his daily life in which every human being has different needs and obligations and is also supported by existing transportation facilities in the place where they live. Besides the discussion about way finding is very complex because many people still don't understand the characteristics in each region in each individual or group. Furthermore, to support this, it is necessary to pay attention to the characteristics in each region. This research was conducted using a questionnaire measuring tool that was distributed directly and online. Obtained from fifty respondents for direct questionnaires and fiftyseven for online questionnaires. The data were analyzed using independent sample t-test and one sample t-test to know how much the influence of the factors influencing someone's characteristics in finding a way in Jabodetabek. Based on the results of the study, the age factor has the greatest influence on a person's characteristics in finding a way. When compared with respondents in their gender and monthly expenditure of respondents.
\end{abstract}

Keywords: a person's characteristics in finding a way; finding a way; way finding.

\begin{abstract}
ABSTRAK
Transportasi terjadi karena adanya keharusan manusia untuk memenuhi kebutuhannya yang tidak dapat dipenuhi ditempatnya saat itu berada. Kegiatan ini dipengaruhi oleh karaketeristik setiap orang dalam mencari jalan. Karakteristik seseorang pastinya di pengaruhi dari kehidupan dia sehari-hari yang dimana setiap manusia mempunyai kebutuhan dan kewajiban yang berbeda-beda dan juga di dukung oleh fasilitas transportasi yang ada pada tempat mereka hidup. Disamping itu juga bahasan tentang wayfinding amat kompleks karena banyak sekali yang belum memahami karakteristik di setiap daerah pada masing-masing individu dan kelompok. Maka untuk menunjang hal itu perlu di perhatikan setiap karakteristik setiap daerah masing-masing. Penelitian ini dilakukan untuk mengetahui variabel yang paling mempengaruhi karakteristik seseorang dalam mencari jalan di Jabodetabek. Penelitian ini dilakukan dengan menggunakan alat ukur kuesioner yang disebarkan secara langsung dan secara online. Didapatkan sebanyak lima puluh responden untuk kuesioner langsung dan lima puluh tujuh responden untuk kuesioner online. Data dianalisis menggunakan independent sample t-test dan one sample t-test untuk mengetahui seberapa besar pengaruh faktor-faktor yang diduga mempengaruhi karakteristik seseorang dalam mencari jalan di Jabodetabek. Berdasarkan hasil penelitian, faktor usia memiliki pengaruh paling besar dalam karakteristik seseorang dalam mencari jalan. Jika dibandingkan dengan responden pada jenis kelaminnya dan pengeluaran responden perbulannya.
\end{abstract}

Kata kunci: karakteristik seseorang dalam mencari jalan; mencari jalan; wayfinding.

\section{PENDAHULUAN}

Wayfinding adalah kunci visual yang memungkinkan orang untuk menavigasi melalui ruang dengan menyediakan informasi untuk membantu mereka menemukan cara bekerja bagaimana mereka bisa sampai ke tujuan yang mereka inginkan. Signage menggabungkan semua informasi visual yang berkaitan dengan lokasi dan merupakan manifestasi wayfinding. Apa pun definisi yang dikatakan oleh para ahli, tetapi wayfinding memang memiliki fungsi untuk menuntun orang agar mencapai tempat tujuan tertentu. Wayfinding merupakan elemen penting dalam sebuah kota atau pun tempat, karena akan sangat membantu orang banyak. Manusia dengan gangguan 
pendengaran akan merasa kesulitan saat ingin menggunakan transportasi perkotaan. Hal ini dikarenakan mereka tidak dapat berkomunikasi secara normal dengan orang lainnya. Mereka biasanya mengandalkan indera penglihatan saat berada di tempat umum. Maka dari itu mereka akan bergantung dengan informasi yang bebentuk tulisan maupun gambar untuk dapat mereka mengerti.

Oleh karena itu dalam penyusunan "Karakteristik Seseorang Dalam Mencari Jalan” ini penulis menyajikan sebuah pengentahuan yang apa adanya di dapat dari kehidupan seseorang yang berbeda-beda dari faktor sosial maupun dari segi akademis. Yang dimana hal ini harus di perjelas untuk membantu menemukan karakteristik dari setiap daerah terutama Jabodetabek yang sudah terlalu rumit untuk di benahi keadaan transportasinya.

Karakteristik seseorang pastinya di pengaruhi dari kehidupan dia sehari-hari yang dimana setiap manusia mempunyai kebutuhan dan kewajiban yang berbeda-beda dan juga di dukung oleh fasilitas transportasi yang ada pada tempat mereka hidup. Di samping itu juga bahasan tentang wayfinding amat kompleks karena banyak sekali yang belum memahami karakteristik di setiap daerah pada masing-masing individu dan kelompok. Maka untuk menunjang hal itu perlu di perhatikan setiap karakteristik setiap daerah masing-masing

Dalam pembangunan fasilitas publik dan fasilitas transportasi umum di Jakarta, Bogor, Depok, Tangerang dan Bekasi (Jabodetabek) sebagian besar masih belum memenuhi standar minimal suatu konsep wayfinding yang cukup terperinci.

Permasalahan yang dapat diidentifikasi dalam hal fasilitas publik, fasilitas pribadi, dan fasilitas transportasi umum terhadap kaitannya dengan wayfinding :

1. Fasilitas angkutan umum yang masih belum memenuhi standar kemudahan bagi para penumpang untuk membantu wayfinding para pengguna.

2. Pelayanan sosial dan mobilitas para pengguna jalan kurang memenuhi dalam membantu pengguna jalan dalam wayfinding.

3. Rambu lalu lintas, marka dan informasi di Jabodetabek kurang memberikan petunjuk yang belum dapat dipahami oleh semua orang serta karaktersistik seseorang dalam wayfinding masih banyak yang belum terlalu memahami perbedaan petunjuk jalan dan petunjuk wayfinding.

Batasan masalah pada penelitian ini adalah:

1. Karakteristik seseorang dalam mencari jalan di batasi oleh daerah pada Jakarta, Bogor, Depok, Tangerang, Bekasi.

2. Sarana pada penelitian ini yaitu semua transportasi umum dan kendaraan pribadi yang terletak di kota Jakarta, Bogor, Depok, Tangerang, dan Bekasi.

3. Prasarana pada penelitian ini yaitu semua prasarana umum maupun pribadi yang terletak di kota Jakarta, Bogor, Depok, Tangerang, dan Bekasi.

4. Lingkup pembahasan dalam penelitian ini membahas aspek aksesibilitas fisik dan non fisik.

Masalah-masalah yang dapat dirumuskan pada penelitian ini adalah sebagai berikut:

1. Bagaimana kondisi pada fasilitas sarana dan prasarana transportasi umum maupun kendaraan pribadi Jabodetabek bila dihubungkan dengan kebutuhan dan karakteristik seseorang dalam mencari jalan?

2. Apakah layanan berupa fasilitas dalam sarana dan prasarana di Jabodetabek cukup memadai sesuai karaktersitik seseorang mencari jalan?

3. Apa saja hambatan yang dirasakan oleh seseorang dalam mencari jalan akan sarana dan prasarana transportasi umum?

4. Apakah rambu-rambu lalu lintas dan rambu-rambu petunjuk pada sarana dan prasarana transportasi untuk kepentingan seseorang mencari jalan sudah cukup baik?

5. Apa saja yang dibutuhkan oleh seseorang mencari jalan akan sarana dan prasarana transportasi umum sesuai karakteristiknya di Jabodetabek yang belum disediakan oleh pemerintah?

6. Apakah aplikasi pada telepon genggam sudah memadai untuk setiap kalangan dan sesuai karakteristik seseorang dalam mencari jalan pada Jabodetabek?

7. Apakah sejauh ini pemerintah sudah cukup baik dalam memenuhi kebutuhan seseorang mencari jalan sesuai karakteristiknya pada sarana dan prasarana transportasi umum sesuai dengan ketentuan dan peraturan yang sudah ada pada Jabodetabek?

Tujuan dari penelitian ini adalah:

1. Memaparkan karakteristik seseorang dalam mencari jalan dalam sarana dan prasarana transportasi umum maupun pribadi pada daerah Jabodetabek. 
2. Mengetahui dampak yang mempengaruhi karakteristik seseorang dalam mencari jalan sesuai sarana dan prasarana transportasi umum maupun pribadi pada daerah Jabodetabek.

\section{Wayfinding}

Secara etimologi, istilah wayfinding terdiri dari dua kata, yaitu way dan find. Menurut www.dictionary.com, salah satu pengertian kata way adalah "a direction or vicinity; a path or course leading from one place to another" suatu arah, suatu jalan yang menuntun dari satu tempat ke tempat lain. Sedangkan kata find merupakan kata kerja dari kegiatan menemukan atau menempatkan, "to locate, attain, or obtain by search or effort". Secara sekilas wayfinding dapat diartikan sebagai penemuan arah dari satu tempat ke tempat lain.

\section{Aplikasi wayfinding}

Aplikasi wayfinding banyak di temukan di setiap harinya dari digital hingga non digital dalam kehidupan seharihari yang banyak kita semua gunakan. Adapun pengaplikasian wayfinding sendiri pasti kita temui sehari-hari dalam setiap tempat,dan juga hal tersebut menjadi sebuah hal lama yang kita gunakan sehari-hari.

Menurut Young (2017), rata-rata pengguna kendaraan bermobil memilih jalan yang umum untuk menuju suatu tempat dengan berkendara berkali-kali melewati jalan yang sama. Hasil saat ini menunjukkan bahwa keakraban jalan, dikembangkan melalui pengulangan rute selama beberapa minggu, tampaknya mengalihkan perhatian pengemudi dari jalan itu sendiri (terutama di lokasi yang jauh) ke area off-road adegan yang tidak relevan dengan keselamatan berkendara. Ini mungkin mencerminkan penurunan gairah karena sifat tugas yang berulang, dengan keinginan yang bersamaan untuk mencari rangsangan baru untuk memperbaiki keseimbangan. Memperbaiki rangsangan off-road diskrit dapat mencerminkan upaya untuk mempertahankan keterlibatan dengan rangsangan eksternal dan mencegah pikiran berkeliaran ke pikiran internal, meskipun tanpa menyelidiki pikiran pengemudi, baik selama perjalanan (mengganggu aliran alami tugas), atau secara retrospektif (yang tergantung pada apakah pikiran-pikiran yang singkat itu diletakkan dalam ingatan). Apakah pengemudi berusaha untuk mempengaruhi pilihan fokus eksternal atau internal dari pikiran mereka yang berkelana, dan hubungannya dengan gerakan mata, menawarkan jalan yang menarik untuk penelitian di masa depan. Namun dapat di perkuat dengan adanya jurnal mengenai sensation seeking adalah trait yang dicirikan oleh kecenderungan untuk mencari sensasi dan pengalaman yang baru, beragam, dan ekstrem, serta keinginan untuk mengambil risiko, baik itu secara fisik, sosial, legal, dan finansial (Zuckerman, 2007).

\section{Ketentuan aplikasi wayfinding dalam kehidupan sehari-hari}

Menurut Meurer dkk (2018), saat ini digitalisasi biaya mobilitas sedang berjalan dengan cepat. Mobilitas bantuan TIK seperti "Google Maps", "Google Now", "Foursquare", "Qype", "Quixxit" atau "Yelp" semakin memengaruhi cara menemukan jalan. Beberapa layanan seperti "Lyft", "Zoomride", "Car2go", atau "Uber" dapat diakses di mana-mana.

Analisis data peta mengarah pada identifikasi lima praktik pencarian jalan:

(1) pencarian jalan menuju tempat-tempat biasa,

(2) pencarian jalan dalam kunjungan pertama kali,

(3) cara menemukan dalam kerjasama ridesharing,

(4) pencarian jalan menuju tempat-tempat tertentu, dan

(5) pencarian jalan menuju tempat-tempat yang dicintai.

Oleh karena itu, meskipun tidak ingin dan tidak dapat diklaim bahwa praktik-praktik ini hanya membahas kelompok pengguna lansia, hasil menunjukkan betapa praktik-praktik tersebut signifikan bagi kelompok pengguna dalam beberapa cara yang sangat spesifik. Temuan lebih lanjut mengungkapkan bagaimana bantuan mobilitas TIK untuk orang tua dapat diterapkan dan disesuaikan untuk lebih mendukung praktik-praktik tersebut.

Aplikasi secara digital memang modern namun ada keterbatasan dalam menggunakannya karena itu menurut Krainz dkk (2016) teknologi modern menyediakan berbagai aplikasi untuk navigasi dan perutean, tetapi ini tidak selalu dapat diakses oleh siapa pun. Orang-orang dengan kebutuhan khusus memiliki persyaratan berbeda untuk jalur jalan yang disarankan dan juga tuntutan lain untuk antarmuka pengguna.

\section{Wayfinding task}

Dalam proses pelaksanaannya, wayfinding dapat dibagi menjadi beberapa tahapan, yaitu menetapkan tujuan, menentukan titik-titik patokan, dan bereksplorasi sepanjang jalur seperti yang terlihat pada gambar 1 berikut. 


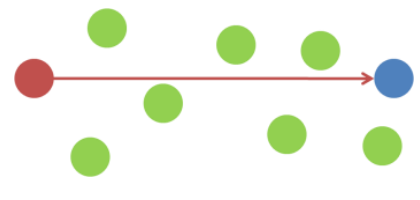

Menetapkan tujuan

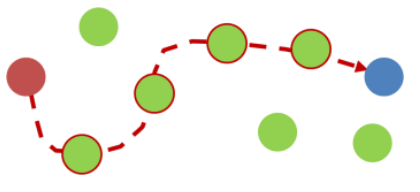

Menentukan titik-titik patokan

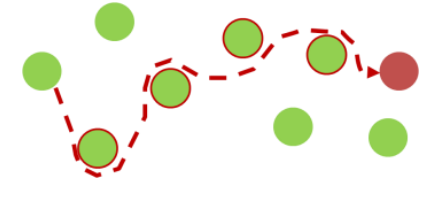

Bereksplorasi sepanjangjalur

Gambar 1. Tahapan wayfinding

Langkah pertama adalah menetapkan tujuan. Tujuan terkadang seluruhnya ditetapkan berdasarkan action plans, tapi pada kasus lainnya mungkin terdapat satu set pilihan dari tujuan yang kurang lebih sama, seperti dinyatakan Garling et al. “...in other cases there may exist a choice set or more or less equivalent destinations” (Garling et al., 1986). Informasi mengenai lokasi relatif suatu tempat perlu dimasukkan dalam action plans. Tanpa informasi ini seseorang dapat mencari secara sembarangan dan dapat kehilangan lokasi yang dituju, "Without this information we would have to search haphazardly, hitting or missing desired locations in a very inefficient way"'(Bell et al., 2001).

Langkah kedua ialah menentukan titik-titik patokan (decision point) sepanjang jalur. Hal ini membutuhkan pengetahuan bagaimana seseorang terkait dengan tempat- tempat lainnya dalam lingkungan. Tujuan yang dipilih harus dapat dilokalisir, sebab untuk mencapai tempat yang dimaksud seseorang harus memiliki suatu ide mengenai dimana untuk menemukannya dalam lingkungan. "The destination chosen is localized-in order to reach a given place one should have some idea about where to find it in the environment" (Garling et al., 1986). Langkah ini membutuhkan kemampuan untuk membuat koneksi kognitif antara lokasi saat ini dengan tujuan yang diinginkan. Rute yang benar harus terhubung dengan titik awal. Dalam lingkungan urban, seringkali tidak ada jalur langsung untuk lurus mencapai tujuan tanpa harus menghindari rintangan atau halangan apapun. Biasanya juga terdapat lebih dari satu rute yang memungkinkan untuk menuju tujuan. Pilihan rute yang akan diambil tergantung pada pertimbangan individual dan faktor eksternal, sebagai contoh, jarak rute, konstitusi jalur, keamanan, kesederhanaan, atau pusat perhatian sepanjang rute. Pilihan rute tersebut juga bisa ditentukan sebelum bepergian, sebagaimana diungkapkan Heuten et al., "The choice can also take place before traveling, which usually leads to route instructions, an external representation of decision points and directions" (Heuten et al., 2008).

Langkah ketiga adalah bereksplorasi atau mulai menjelajah jalur. Jaringan path menyediakan dasar untuk pergerakan dalam lingkungan urban. Dalam tahap eksplorasi ini seseorang harus menjaga untuk tetap berada di jalur yang benar, hal ini mengacu pada pengawasan rute dan menjaga diri untuk tetap berada dalam jalur yang dipilih selama pergerakan, "... keeping on the right track, refers to the monitoring of the route and ensures during the movement that people are still on the chosen way. This includes that the traveler makes the right decisions at the decision points" (Heuten et al., 2008). Langkah ini mencakup pembuatan keputusan yang benar pada titik patokan/decision point. Selama aktivitas ini penjelajah secara konstan mengorientasi dirinya dalam lingkungan dan memetakan lokasi dirinya sekarang pada peta kognitif, "During this activity the traveller constantly orientates oneself in the environment and maps the current location onto the cognitive map" (Heuten et al., 2008). Heuten juga menekankan bahwa landmark memainkan peranan penting dalam aktifitas ini, "Landmarks play an important role in this activity" (Heuten et al., 2008), sebab landmark akan diamati secara permanen oleh penjelajah. Rotasi atau pergerakan apapun memberi hasil pada persepsi terhadap landmark dari perspektif berbeda, hal ini dapat menandai apakah pergerakan benar mendekati tujuan atau justru menjauh, dan menegaskan bahwa penjelajah masih berada dalam rutenya. Penjelajah juga harus memberi penyesuaian untuk menjaga rute, seperti menghindari rintangan dan kembali pada rute, "In addition, the navigator performs adjustments to keep track on the current path, like the sidewalk, avoiding obstacles, and returning to the route" (Heuten et al., 2008).

\section{Strategi wayfinding}

Berdasarkan pandangan mengenai proses kognitif terkait wayfinding dan tahapan tugas dalam proses wayfinding dapat disimpulkan bahwa untuk dapat menjalankan proses ini, manusia bergantung kepada informasi yang diberikan oleh lingkungan. Kemampuan yang digunakan manusia dalam proses wayfinding antara lain kemampuan kognitif, kemampuan perencanaan, dan kemampuan berperilaku, seluruh kemampuan tersebut merupakan hasil interaksi manusia secara individual dengan lingkungannya. 
Untuk mengidentifikasi lingkungan, manusia secara aktif menggunakan segala penginderaan. Indera penglihatan merupakan indera yang paling dominan bagi manusia untuk menilai lingkungan sekitarnya. Informasi visual sangat mempengaruhi terciptanya kesan terhadap lingkungan.

Dari pembahasan sebelumnya dapat disimpulkan bahwa tahapan tugas yang dilakukan manusia dalam proses wayfinding adalah menetapkan tujuan, menentukan patokan dan jalur, dan bereksplorasi.

Bagian penting pada tahapan tersebut adalah pada saat manusia harus memastikan dirinya tetap berada dalam jalur. Karena untuk menjaga rute dalam proses wayfinding, manusia perlu memberi penyesuaian seperti menghindari rintangan, sehingga adakalanya manusia keluar dari rute. Oleh karena itu manusia memerlukan patokan untuk kembali pada rute, memastikan apakah pergerakan benar mendekati tujuan atau justru menjauh. Patokan-patokan ini tidak lain merupakan isyarat dari lingkungan yang ditangkap manusia. Strategi manusia dalam wayfinding berkaitan dengan bagaimana patokan-patokan dijadikan sebagai referensi orientasi selama pergerakan.

a. Fleksibel dalam penggunaan (Flexibility in Use): dapat mengakomodasi kebutuhan dan kemampuan individual yang beragam.

b. Sederhana dan intuitif (Simple \& Intuitive): mudah dimengerti, terlepas dari perbedaan latar belakang, pengalaman, pengetahuan, bahasa, kecakapan maupun tingkat konsentrasi penggunanya.

c. Mudah dan cepat dipersepsi secara inderawi (Perceptable Information): secara efektif dapat menyampaikan informasi yang diperlukan oleh pengguna, terlepas dari situasi, tingkat kondisi dan kemampuan inderawi penggunanya.

d. Toleransi terhadap kesalahan (Tolerance for error): mampu mengurangi resiko bahaya, kerugian akibat kecelakaan atau kejadian yang tidak diinginkan.

e. Upaya fisik yang rendah (Low Physical Effort): dapat digunakan secara efisien, nyaman dan dengan tingkat kelelahan yang rendah.

f. Ukuran dan ruang untuk kenyamanan pengguna (Size and space for Approach \& Use): penggunaan ukuran dan ruang yang wajar dan pantas sebagai pendekatan, pencapaian, dan penggunaan, terlepas dari ukuran tubuh, postur atau mobilitas penggunanya.

\section{METODE PENELITIAN}

Alur atau tahapan dari penelitian ini tertera dalam bentuk diagram seperti pada gambar 2 di bawah ini.

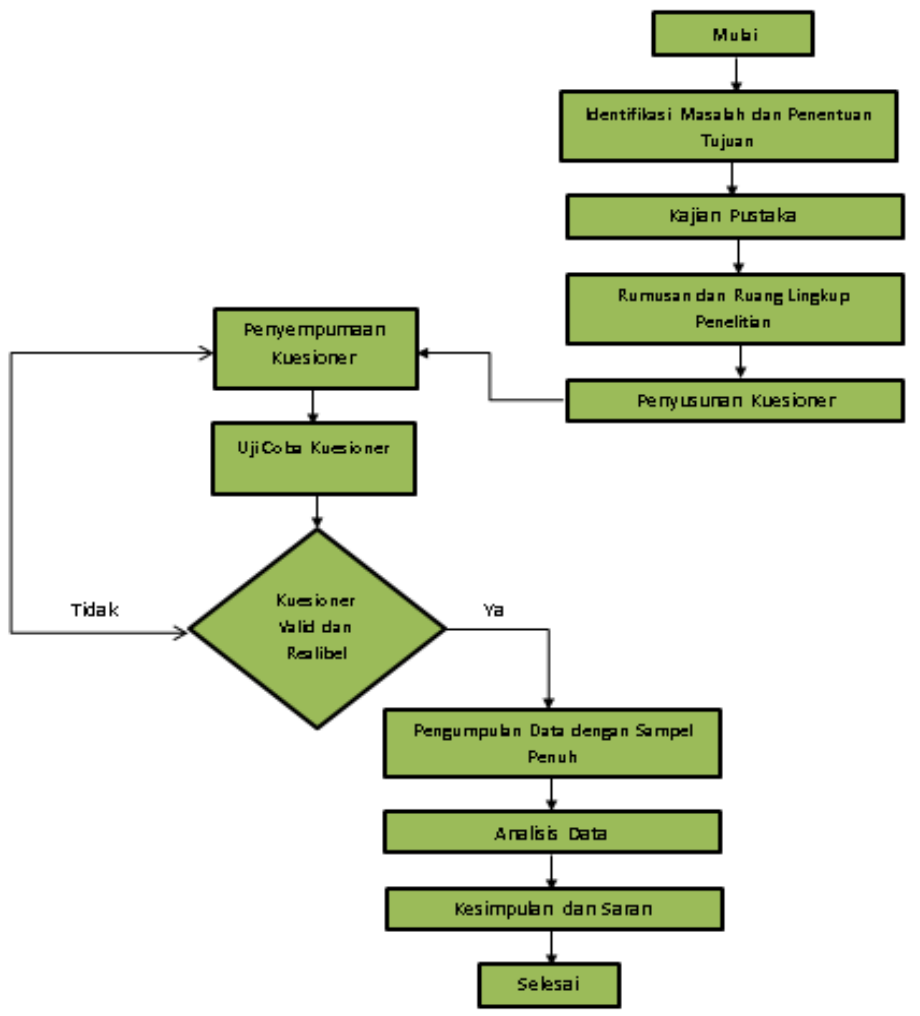

Gambar 2. Diagram alur penelitian 
Subjek peneletian pada penelitian ini adalah para seluruh aspek sosial yang hidup pada daerah Jabodetabek. Jumlah responden pada penelitian ini adalah 100 orang, yang dimana 50 kuesioner dalam selebaran dan 50 kuesioner dalam google forms. Lokasi penelitian pada penelitian ini adalah kota Jakarta, Bogor, Depok, Tangerang, dan Bekasi (Jabodetabek).

Pengumpulan data dilakukan melalui kuesioner dengan pertanyaan yang berkaitan dengan tujuan dari penelitian ini. Daftar pertanyaan (kuesioner) dalam bentuk google forms serta dalam bentuk selebaran yang dibuat untuk memperoleh data-data primer yang disusun berdasarkan parameter-parameter analisis yang dibutuhkan dan relevan sesuai dengan maksud dan tujuan dari penelitian ini yang ditujukan kepada responden yang sudah ditentukan sebelumnya.

Pengumpulan data dilakukan melalui kuesioner dengan pertanyaan yang berkaitan dengan tujuan dari penelitian ini. Pertanyaan tersebut didasari oleh aspek dan kriteria pada peneletian ini. Data yang diambil dari kuesioner ini adalah dimana keberadaan fasilitas umum dan pribadi yang paling penting, jenis fasilitas umum dan pribadi apakah yang lebih mempengaruhi, serta eksisting fasilitas umum dan pribadi yang ada pada saat ini menurut para responden.

Aspek pada peneletian ini adalah:

- Sarana transportasi kota di Jabodetabek (Kereta KRL Commuter Line, Bis Transjakarta, Kereta MRT Jakarta)

- Prasarana transportasi kota di Jabodetabek (Stasiun KRL Commuter Line, Halte Transjakarta, Stasiun MRT Jakarta)

- Prasarana akses menuju ke prasarana transportadi kota terdekat

Kriteria pada peneletian ini adalah:

- Sarana transportasi kota di Jabodetabek

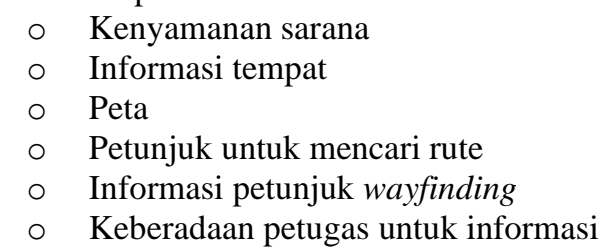

- Prasarana transportasi kota di Jabodetabek
- Kenyamanan sarana
- Informasi wayfinding
- Petunjuk arah rute

- Prasarana akses

$\begin{array}{ll}\circ & \text { Trotoar } \\ \circ & \text { Jembatan penyebrangan orang } \\ \circ & \text { Zebra cross } \\ \circ & \text { Penunjuk arah } \\ \circ & \text { Penunjuk rute perjalanan } \\ \circ & \text { Lampu lalu lintas } \\ \circ & \text { Polisi lalu lintas }\end{array}$

\section{Variabel penelitian}

Variabel penelitian adalah segala sesuatu yang berbentuk apa saja yang ditetapkan oleh peneliti untuk dipelajari sehingga diperoleh informasi tentang hal tersebut, kemudian ditarik kesimpulannya.

\section{Kuesioner}

Dalam penelitian ini kuesioner disusun dengan menggunakan metode pemberian nilai untuk menentukan yang mana yang lebih sering di lakukan dengan memberi nilai dari 1-4 dengan masing-masing angka mempunyai pengertian masing-masing. Definisi dari masing-masing angka tertera pada tabel 1. Untuk pemberian nilai hal-hal yang lebih setuju di lakukan, digunakan penilaian seperti pada tabel 2. 
Tabel 1. Pengertian nilai untuk menentukan yang manakah yang hampir tidak pernah hingga sering sekali pada kuesioner

\begin{tabular}{lc}
\hline Nilai & Definisi \\
\hline 1 & Hampir tidak pernah \\
2 & Tidak pernah \\
3 & Sering \\
4 & Sering sekali \\
\hline
\end{tabular}

Tabel 2. Pengertian nilai untuk menentukan sangat tidak setuju sampai sangat setuju

\begin{tabular}{lc}
\hline Penilaian & Definisi \\
\hline 1 & Sangat Tidak Setuju \\
2 & Tidak Setuju \\
3 & Setuju \\
4 & Sangat Setuju \\
\hline
\end{tabular}

Pada Peneletian ini analisa data yang digunakan terdiri dari 2 jenis analisis. Analisis data untuk mengetahui aspek dan kriteria yang lebih penting sesuai dari jawaban kuesioner responden, akan digunakan metode analisis data untuk mengetahui eksisting variabel pada saat ini, akan digunakan program Statistical Package for Social Sciences (SPSS).

Berikut adalah tahapan-tahapan pemodelan SPSS dan pengerjaan penelitian ini pada bab rangkuman data dan analisis data yang akan dilakukan pada penelitian ini adalah sebagai berikut:

1. Memasukan data kuisoner kedalam program Excel.

2. Melakukan Rekap data pada program Excel untuk dimasukkan pada program SPSS.

3. Memasukan hasil rekap pada program Excel pada bab rangkuman data.

4. Memasukkan data dengan program SPSS.

5. Melakukan uji validitas dengan SPSS.

6. Melakukan uji reabilitas dengan SPSS.

7. Melakukan uji komperasi one sample T-Test dengan program SPSS.

8. Melakukan pembagian data dalam bentuk coding untuk memulai penelitian uji komperasi independet sample T-test dengan program SPSS.

9. Melakukan uji komperasi independet sample T-test dengan program SPSS.

10. Melakukan identifikasi hasil pada program SPSS

11. Melakukan input data hasil program SPSS pada bab analisis data.

12. Melakukan input hasil data untuk menemukan kesimpulan dan saran pada penelitian ini.

\section{HASIL DAN PEMBAHASAN}

Pada bab ini menyajikan hasil dan pengolahan data menggunakan software IBM SPSS Statistics 25 yang dilakukan terhadap seseorang yang berdomisili atau beraktifitas sehari-hari di Jabodetabek. Survei ini bertujuan untuk mendapatkan data karakteristik seseorang dalam mencari jalan.

Pada rangkuman data yang didapatkan berkaitan dengan beberapa indikator/aspek pertanyaan yaitu informasi dan ketersediaan umum yang terdapat di perjalanan, informasi dan ketersediaan pribadi yang terdapat diperjalanan, waktu yang diperhitungkan saat perjalanan, situasi kondisi seseorang dalam mencari jalan dan kebijakan pemerintah dalam mencari jalan.

\section{Karakteristik distribusi responden}

Pada awal perencanaan penelitian, jumlah responden yang direncankan berjumlah 100 orang, dengan pembagian 50 orang kuesioner secara langsung dan 50 orang kuesioner secara online. Jumlah hasil responden yang didapatkan setelah dilakukan pembagian kuesioner adalah 107 orang. Pada pembagian kuesioner secara langsung didapatkan 50 orang dan pada pembagian kuesioner secara online didapatkan 57 orang. Perbedaan jumlah 
responden dapat dilihat pada tabel 3. Responden yang mengisi kuesioner adalah para setiap orang yang berdomisili atau beraktifitas sehari-hari di Jabodetabek. Responden di ambil secara acak dan dibatasi oleh daerah Jabodetabek.

Data-data responden yang terdapat dalam kuesioner adalah data umum berupa jenis kelamin responden, usia responden (seperti terlihat pada tabel 4), pendidikan terakhir responden, pengeluaran responden selama sebulan, jenis kendaraan pribadi yang sering digunakan responden, jenis kendaraan umum yang sering digunakan responden, Profesi responden, serta frekuensi kendaraan umum maupun pribadi yang sering digunakan sehari-hari.

Tabel 3. Perbedaan jumlah responden rencana dan realisasi

\begin{tabular}{lccc}
\hline \multirow{2}{*}{$\begin{array}{l}\text { Jenis } \\
\text { Kelamin }\end{array}$} & Jenis & \multicolumn{2}{c}{ Jumlah Responden } \\
& Kelamin & Rencana & Realisasi \\
\hline \multirow{3}{*}{ Laki-laki } & L & 25 & 24 \\
& O & 25 & 40 \\
& G & 50 & 64 \\
Perempuan & L & 25 & 15 \\
& O & 25 & 28 \\
Total & $\mathrm{G}$ & 50 & 43 \\
\hline
\end{tabular}

Keterangan : $\quad \mathrm{L}=$ Kuesioner secara langsung.

$\mathrm{O}=$ Kuesioner secara online.

$\mathrm{G}=$ Jumlah kuesioner gabungan antara kuesioner langsung dan kuesioner online.

Tabel 4. Jumlah responden pada kuesioner berdasarkan jenis kelamin dan usia responden

\begin{tabular}{ccc}
\hline Usia (tahun) & Laki-Laki & Perempuan \\
\hline $17-20$ & 5 & 5 \\
$21-30$ & 48 & 30 \\
$31-40$ & 9 & 3 \\
$>40$ & 2 & 5 \\
& 64 & 43 \\
Total & \multicolumn{3}{c}{107} \\
\hline
\end{tabular}

Dewasa adalah individu yang telah menyelesaikan pertumbuhannya dan siap menerima kedudukan dalam masyarakat bersama dengan orang dewasa lainnya (Hurlock, 1980). Pembagian pada kategori usia adalah sebagai berikut :

- Masa Dewasa Dini

Masa dewasa dini dimulai pada umur 18 tahun sampai kira-kira umur 40 tahun. Saat perubahanperubahan fisik dan psikologis yang menyertai berkurangnya kemampuan reproduktif.

- Masa Dewasa Madya

Masa dewasa madya dimulai pada umur 40 tahun sampai pada umur 60 tahun, yakni saat baik menurunnya kemampuan fisik dan psikologis yang jelas Nampak pada setiap orang.

- Masa Dewasa Lanjut (Usia Lanjut)

Masa dewasa lanjut atau usia lanjut dimulai pada umur 60 tahun sampai kematian. Pada waktu ini baik kemampuan fisik maupun psikologis cepat menurun, tetapi teknik pengobatan modern, serta upaya dalam hal berpakaian dan dandanan, memungkinkan pria dan wanita berpenampilan, bertindak dan berperasaan seperti kala mereka masih lebih muda.

Oleh karena itu untuk pembagian umur pada analisis data di bagi menjadi dua bagian yang pertama dibawah 40 tahun dan lebih dari 40 tahun.

Untuk data umum pengeluaran perbulan karena rata-rata kehidupan di daerah Jabodetabek sesuai upah minimum provinsi yang terbilang seimbang dari seluruh daerah Jabodetabek, hal ini dapat dilihat :

- Jakarta : Rp.3.900.000

- Bogor : Rp.4.169.806 


$\begin{array}{lll}\text { - } & \text { Depok } & \text { :Rp.4.202.105 } \\ \text { - Tangerang } & \text { : Rp.3,869,717 } \\ \text { - } & \text { Bekasi } & \text { : Rp.4.498.961 }\end{array}$

Berikut pada tabel 5 disajikan data jumlah responden berdasarkan pengeluaran per bulan.

Tabel 5 Jumlah responden pada kuesioner berdasarkan pengeluaran per bulan

\begin{tabular}{ccc}
\hline Pengeluaran perbulan $(\mathrm{Rp})$ & Laki-Laki & Perempuan \\
\hline $0-2.000 .000$ & 20 & 20 \\
$2.000 .000-4.000 .000$ & 21 & 13 \\
$4.000 .000-6.000 .000$ & 13 & 4 \\
$>6.000 .000$ & 10 & 6 \\
& 64 & 43 \\
Total & \multicolumn{2}{c}{107} \\
\hline
\end{tabular}

\section{Compare One-sample T test kelompok aspek setiap variabel pada butir pertanyaan}

Jika dilihat secara umum setiap pertanyaan di atas kuisoner rata-rata nilai yang dijawab oleh responden diatas 2,5 poin, hanya saja pada pertanyaan mengenai bertanya langsung di jalan, menggunakan peta manual, efektivitas peta manual, bertanya dengan pesan singkat, dan menanyakan petugas pada trasportasi umum yang angka rata-ratanya dibawah 2,5 dan pertanyaan yang angka rata-ratanya diatas 2,5 adalah memperhatikan peta rute transportasi umum, jabodetabek harus mempunya pentujuk jalan atau wayfinding yang baik, pentujuk jalan yang terinci, petunjuk jalan yang efektif, merencanakan pemilihan jalan terlebih dahulu, menggunakan peta dari telefon genggam, penggunakan aplikasi petunjuk jalan efektif, menanyakan patokan tempat yang ingin di tuju, memperhatikan rute terpendek, tidak tersesat dalam pemilihan rute perjalanan, memilih rute tercepat, sudah tau arah yang di tuju, dipengaruhi oleh jenis perjalanan tentang rute yang di tuju, kondisi situasi saat perjalanan mempengaruhi saat ingin menuju tempat yang di tuju, dan kebijakan ganjil genap yang mempengaruhi pemilihan jalan. Hal ini menunjukan sikap responden yang tidak sepakat akan pertanyaan yang di tanyakan untuk mereka. Dapat dilihat masing-masing pertanyaan itu merujuk hal-hal yang mungkin sudah ditinggalkan oleh para responden yang beraktivitas di Jabodetabek.

Jika dibandingkan dengan faktor lain-lain, bisa dilihat data yang membandingkan antar umur, jenis kelamin, dan pengeluaran perbulan responden pada Jabodetabek.

\section{KESIMPULAN DAN SARAN}

\section{Kesimpulan}

Berdasarkan penelitian yang telah dilakukan dapat disimpulkan sebagai berikut:

1. Responden sudah sangat jarang ditemui yang menggunakan peta manual dan sudah juga jarang ditemui pula yang bertanya langsung dengan seseorang di jalan dalam mencari jalan.

2. Secara umum, responden di Jabodetabek Sudah mulai meninggalkan kebiasaan bertanya langsung dijalan, menggunakan peta manual, keyakinan pada efektifitas peta manual, bertanya dengan pesan singkat, dan bertanya kepada petugas transportasi umum.

3. Kelompok responden laki-laki, umur diatas 40 tahun, dan yang pengeluaran per bulannya lebih besar dari Rp.4.000.000, cenderung menggunakan peta manual.

4. Kelompok responden perempuan, cenderung memiliki kemampuan mengetahui rute transportasi umum.

5. Kelompok responden umur dibawah 40 tahun, cenderung menggunakan peta dari telepon genggam.

6. Kelompok responden umur diatas 40 tahun, lebih membutuhkan petunjuk jalan yang jelas saat melakukan perjalanan.

\section{Saran pemanfaatan penelitian}

Berdasarkan penelitian dan penarikan kesimpulan yang telah dilakukan dapat direkomendasikan saran terhadap pemanfaatan penelitian ini, yakni: 
1. Penelitian ini dapat digunakan sebagai dasar pertimbangan desain transportasi terpadu pada suatu wilayah dalam rangka memperbaiki maupun merencanakan lalu lintas terutama masyarakatnya agar di mudahkan dalam mencari jalan.

2. Adanya perbedaan karakteristik wayfinding berdasarkan kelompok usia $\geq 40$ tahun agar dapat di perhatikan setiap kebutuhan aspek sarana dan prasarana untuk semua masyarakat di Jabodetabek.

3. Masyarakat zaman sekarang lebih suka menggunakan telepon genggam karena lebih praktis dan canggih, oleh karena itu hal ini dapat di perhatikan untuk perkembangan transportasi online yang dapat mendukung kegiatan sehari-hari yang lebih efisien, aman, dan nyaman.

\section{Saran terhadap penelitian selanjutnya}

Berdasarkan penelitian yang sudah dilakukan dapat direkomendasikan saran terhadap penelitian selanjutnya, yakni:

1. Memusatkan perhatian terhadap variabel-variabel yang dibutuhkan saja sehingga menghindari kuesioner yang sulit dimengerti. Hal tersebut dapat menyebabkan responden menjadi rancu saat mengisi kuesioner.

2. Meneliti secara khusus hubungan antara satu kelompok variabel dengan kelompok variabel lainnya sehingga mendapatkan hasil penelitian yang lebih beragam.

3. Melakukan penelitian secara mendalam dengan wawancara responden untuk menentukan cara pemilihan responden serta latar belakangnya dalam mencari jalan atau melakukan perjalanan.

\section{DAFTAR PUSTAKA}

Bell,. et al. "Environmental Psychology. USA: Thomson Wadsworth", vol. 29, 2001, pp. 358-365., https://doi.org/10.1016/j.jenvp.2009.02.004.

Gärling T., et al. 1986. "The spatiotemporal sequencing of everyday activities in the large-scale environment”, vol. 6, 1986, pp. 261-280., https://doi.org/10.1016/S0272-4944(86)80001-9.

Heuten, W., et al. "Tactile Wayfinder: A non visual Support System for wayfinding.University of Oldenburg”, vol. 22, 2008, pp 172-181., DOI: 10.1145/1463160.1463179.

Hurlock, E.B. Psikologi Perkembangan. Jakarta: Erlangga, 1980.

Krainz, E., et al. “Accessible way finding on mobile devices for different user groups”, vol.18, 2016, pp 297-303., DOI: $10.1007 / 978-3-319-44902-9 \_25$.

Meurer. J., et al. "Designing for Way-finding Practices - A Study about Elderly People's Mobility”,vol 115, 2018, pp 40-51., University Siegen, Institute of Information Systems and New Media, Kohlbettstraße 15, Siegen 57068, Germany., OI: 10.1016/j.ijhcs.2018.01.008.

Young, A., et al. "Familiarity breeds contempt for the road ahead The real-world effects of route repetition on visual attention in an expert driver", vol. 57, 2017, pp 4-9., https://doi.org/10.1016/j.trf.2017.10.004.

Zuckerman, M. Sensation seeking and risky behavior. America: American Psychological Association. 2007. 